\title{
9 \\ The Innovation of Tradition: Reflections on the Ebb and Flow of Heritage Regimes in Fiji
}

\author{
Guido Carlo Pigliasco
}

\section{Background}

Back in July 2008, the session on Cultural Heritage and Political Innovation at the European Society for Oceanists (ESfO) meeting in Verona was slowly moving towards the lunch break. Edvard Hviding, chairing the session, had just finished introducing the last paper of the morning, mine, when a latecomer's steps echoed on the marbled floor of the Sala Farinati in the old civic library. When I looked up, Marshall Sahlins was taking a seat just in front of me, in the front row. After delivering my paper on cultural heritage policymaking in Fiji, I took the first question. That was when Sahlins, half chuckling, spoke up to say that all these efforts to safeguard cultural heritage were quite otiose, for while traditional symbols, medicinal plants and other such elements of cultural heritage might eventually be safeguarded by the law, in the meantime local genealogies representing the most treasured possessions belonging to the very custodians of that cultural heritage were being lost.

I asked him to be more specific, and Sahlins told a little story: a few years earlier, he had begun to research a particular genealogy at the National Archives of Fiji. However, when he returned to Suva a couple of years 
later the material was gone, and he was never able to complete his study. His conclusion? The same might just as easily happen to the tangible or intangible cultural heritage material they are trying to protect now. To me it seemed we were at an impasse. I argued that it is precisely cases like that of the lost genealogy that demand 'cultural mapping' programs, traditional knowledge databases and sui generis legislations. I could tell that Sahlins was genuinely perplexed, as well as unconvinced, but he indulgently allowed the session to come to an end, and we all proceeded to a nearby pizzeria to have lunch.

Anna Paini and Elisabetta Gnecchi-Ruscone (Introduction, this volume) emphasise how this collection of essays, originally arising out of discussions at our ESfO 'Putting People First' themed meeting in Verona, was inspired by the 1993 Suva Declaration. Echoing such a theme, two decades after the Suva Declaration, a Facebook group called NA NODA MASI-Do not TM our Cultural Heritage (hereafter Na Noda Masi), with a couple of thousand Fijian and Pacific Islander followers 'who share a passion for cultural heritage', objected to a trademark application by Fiji Airways to own several masi (bark cloth) kesakesa (designs). ${ }^{1}$ One of the first comments was posted on Facebook by Millie Vulaca Tukana on 14 January 2013:

Sorry Fiji Airways, u can't buy this or put a price tag on it, this was inherited, it is ours, lets all put up masi prints of these as cover photos on our FB \& tell them, this is mine not yours. God bless the Fijian people, God Bless Fiji. Lets cover our profile pic with masi too.

Soon, Na Noda Masi posted a new headline on Facebook: 'The Women of Cakaudrove speak out'. ${ }^{2}$ The Fijian province of Cakaudrove is on the northern island of Vanua Levu. Interviewed by the Fiji Times, Dimitimiti Lewenilovo, president of the Cakaudrove chapter of the Soqosoqo Vakamarama, an organisation devoted to fostering women's crafts, said that the airline's new logo includes designs that are sacred to the vanua

1 Kesa is a liquid dye extracted from the root of the elaeocarpus tree. It is used by renowned Moce Island women artists to stencil cloth made from the bark of the paper mulberry tree with family owned designs (kesakesa) (see Kooijman 1977: 37). In Fiji known as masi, and across the Pacific often as tapa, such cloth can be made in large sheets highly prized for their decorative value, exchanged as valuable gifts, and often still worn on formal occasions such as weddings.

2 Na Noda Masi, 'The women of Cakaudrove speak out', Facebook posting, 10 February 2013. Online: www.facebook.com/photo.php?fbid=659520247407633\&set=a.652745184751806.157522 $.647830625243262 \&$ type $=1 \&$ theater $($ accessed 30 January 2013). 
of Cakaudrove. ${ }^{3}$ The designs are also known as masi bola ni Cakaudrove, and they are used by women in the province to identify the masi they make as being from Cakaudrove. In the interview, Lewenilovo explained:

We have seen it on the newly designed logo of the airline company and this is a concern since these are designs that are ours alone, something that has been part of our identity and we have never been approached or consulted by the company that now lays claim over it (Rawalai 2013).

Sahlins's trenchant comment at Verona, mutatis mutandis, turns out to have been clairvoyant. Fijians, like many other indigenous communities in the Pacific, are in danger of losing control of their most treasured possessions, which have been passed on generation after generation and are now floating in the public domain and in danger of being trademarked by anyone, including, as in the masi case, other Fijians. After all, Sahlins (Chapter 1, this volume) concluded more recently that European imperialism has not been the only source of desire for alterity and quests for potency. As this volume goes to print, it is not even clear if and what kind of settlement is on the table—or perhaps under the table to avoid igniting new clamor-to accommodate the Fiji Airways masi case. ${ }^{4}$ Sadly, the Fiji Airways masi artist Makereta Matemosi, who passed away at her Namuka-i-Lau settlement home outside Lami in late April 2014, will not be able to see its end, or what is perhaps the beginning of such an inconvenient Fijian quarrel. ${ }^{5}$

3 Tomlinson defines the vanua: 'A complex domain encompassing chiefs, their people, land, and tradition' (2009: 6). However, he recently observed that 'the term has become polarized by being defined in one direction as the inherently good foundation of indigenous Fijians' collective identity, and in the other direction as the inherently bad location of demonic influence which thwarts their efforts and holds them back' (Tomlinson 2014: 121).

4 On 19 January 2015, Fijilive reports that Fiji Airways has declined to comment on claims by the people of Moce saying their trademark application was still with authorities. According to the same news however, Ministry of iTukei Affairs Permanent Secretary Savenaca Kaunisela would have indicated 'that it would be hard for Fiji Airways to patent the design because it was not unique, but rather had designs which belong to an iTaukei group'. Online: www.pireport.org/articles/2015/01/20/fiji-airwaysno-comment-over-masi-motif-trademark-allegations (accessed 5 March 2017).

5 In the frequently asked questions section of their petition, the Na Noda Masi group explains that the artist Makereta Matemosi, an emigree in Suva from Moce Island, did not create unique masi motifs for Fiji Airways:

she used masi motifs that have been handed down over the generations in her community. She is not the creator or the only user of those motifs - there are hundreds more masi makers in Fiji who use some or all of these motifs too. So in short: she doesn't own the TM to the motifs since she didn't create it from scratch; since she doesn't own the motifs, the motifs are therefore not hers to give to Fiji Airways for a price; many people commission masi pieces for weddings, significant occasions, but they do not consider that they can then reproduce the masi motifs just because they've paid for one piece (Na Noda Masi, 21 February 2013. Online: www.change.org/petitions/prime-minister-voreqe-bainimarama-appeal-to-stop-airpacific-trademarking-15-distinct-masi-motifs (accessed 21 February 2013)). 
Drawing on a decade of direct observations of cultural mapping and policymaking regarding Fiji's cultural heritage (Pigliasco 2007, 2009a, 2009b, 2011, 2012a), in this chapter I offer a commentary on the work-in-progress efforts, challenges and paradoxes encountered by Fiji policymakers and their consultants in the process of turning thick lore into soft law, inventorying both the materiality and intangibility of iTaukei (indigenous Fijian) cultural heritage and estimating its socially and emotionally ascribed value-one of the most elusive concepts encountered by legal scholars, for questions of 'value as morality' cannot be avoided (see Otto and Willerslev 2013: 15). ${ }^{6}$

\section{Heritage or trademark regimes?}

The 'heritage regime' has recently become a powerful, 'increasingly neoliberal' (Coombe 2012: 378) notion, replacing odd technocratic acronyms and paternalistic definitions of tangible and intangible cultural heritage. Envisioning a set of principles, guidelines and procedures that regulate and valuate cultural resources and human capital with an increasing emphasis on governance priorities, market ideology and global tourism, the idea of heritage regimes is inescapably linked to the gradual UNESCOisation $^{7}$ and bureaucratisation, or 'managerialist gaze' (Coombe and Weiss 2015: 46), of Pacific Island heritage, making visible and tangible the intangible.

I actually can't help but view this chapter as a fated sequel to my timid concerns expressed five years ago in 'Are the grassroots growing?' (Pigliasco 2011). The risk of UNESCOisation triggering friction and conflict between the different scales and actors involved, as in the Fiji Airways case, is now a doomed reality. Chiara De Cesari (2012: 407) and others stress 'the diverse understandings of and stakes in heritage' occurring between international and local experts-the grassroots-

6 As several of my colleagues (see Blake 2014) have pointed out, it is unfortunate that very few international lawyers and legal scholars have engaged with heritage regimes and related topics, leaving a gap in the legal literature and room for non-legal scholar commentators to advance unseemly and unfruitful critical theory of law arguments.

$7 \quad$ Advanced (and feared) by Richard Merritt and Elizabeth Hanson back in 1989, this derisive term was recently revamped by David Berliner (2012) in his work on an ancient royal town of northern Laos designated by United Nations Educational, Scientific and Cultural Organization (UNESCO) as a World Heritage site. 
and also between the state and the grassroots. ${ }^{8}$ In other words, "heritage is a new language of political currency for seeking investment, but it has also assumed enhanced value in advancing the political agendas of grassroots, minority and indigenous actors' (Coombe and Weiss 2015: 56; see also Schofield 2014; Geismar 2015).

Legal scholar Rosemary Coombe's words of wisdom on cultural properties and their politics have never sounded more appropriate: 'attempts to construct new regimes of state-based property rights lag far behind traditional customs, contemporary mores, and, particularly, the new practices, protocols, ethics, and relationships of mutual respect and recognition that have been provoked by cultural property claims' (2009: 407).

In an official press release, Na Noda Masi clearly implies how in Fijian and Pacific Islander epistemology, the infringement takes place by trying to own something, versus simply using it:

We support and applaud Air Pacific for choosing to use masi motifs on the new Fiji Airways fleet. We are proud that our culture is being showcased to the world. But we don't support Air Pacific's application to trademark these motifs. These cultural motifs are used in masi making, mat-weaving, wood-carving and by other artisans and craftspeople. These motifs were not created by Air Pacific and have been handed down over the generations. The trademark means that masi makers, carvers, weavers and our craftspeople will have to ask permission from Air Pacific if they want to use these masi motifs or draudrau in future. We advocate that cultural art should remain in the public domain for all to enjoy. We agree there is a need for legislation which protects our intellectual property but we strongly advocate against any corporation owning cultural practices. We offer our collective support, advice and help in working with the state to find legislation which protects our intellectual property but which does not compromise its integrity.?

$\mathrm{Na}$ Noda Masi's petition created a real momentum on the Internet and was endorsed by various indigenous organisations calling on the Fiji authorities to put in place:

8 See the chapters by Ballacchino, Broccolini, Graezer Bideau, Kockel, and Leblon in Heritage Regimes and the State, ed. Bendix, Eggert and Peselmann (2012).

9 Na Noda Masi, Facebook posting, 6 February 2013. Online: www.facebook.com/ fijimasiforeveryone (accessed 6 February 2013). 
laws to protect these motifs and all forms of cultural expression and traditional knowledge. We hope in future that our culture will continue to be strengthened by being encouraged in schools, that it be celebrated with festivals and continues to be manifested freely by the craftspeople, artisans, designers and people of Fiji. ${ }^{10}$

Na Noda Masi recognises the wider repercussions:

A flash in the pan or long-term change? As many have pointed out, this discussion is much bigger than one company and fifteen designs ... How are we going to protect the many unique aspects of our culture while keeping things fair, dynamic, and authentic into the future? ${ }^{11}$

Clearly, this local incident is becoming a regional and international affair and reflects both the impasse that Fiji and Pacific Island countries are facing and the demand for a policy informing domestic legislations to support the protection of their tangible and intangible heritage sites at the national, regional and international levels. Almost at the same time as the masi case, a pair of Samoan-inspired patterned women's leggings caused significant trouble over at Nike. Nike's tattoo-like, printed 'Tattoo Tech Tights' sparked ire among the transnational Samoan communities in Australia and New Zealand for the design's similarity to the pe'a, the traditional male tattoo in Samoa, forcing the company to pull the product and issue an apology. It is foreseeable that more similar cases will emerge in Fiji and other Pacific Island nations working on strategies to protect their tangible and intangible cultural heritage. Scholars of cultural property have neglected a fundamental tenet of legal anthropology, Coombe argues, namely that identities do not exist before the law but are forged in relation to the law and the subject positions afforded by legal regimes and policy negotiations (Coombe 2011b: 115).

Max Planck Institutes' intellectual property (IP) expert, Silke von Lewinski, observes that developing countries are now showing their muscles in different international fora' (2009: 125). On the other hand, she recognises that the international, regional and even national instruments inspiring this renaissance in the field of IP rights are still too far away from rules with which the local communities could feel comfortable, or they are too

10 Na Noda Masi, Facebook posting, 8 February 2013. Online: www.facebook.com/photo.php ?fbid $=659574510735540 \&$ set $=a .659449237414734 .158457 .647830625243262 \&$ type $=1 \&$ theater (accessed 8 February 2013).

$11 \mathrm{Na}$ Noda Masi, Facebook posting, 10 February 2013. Online: www.facebook.com/ fijimasiforeveryone (accessed 10 February 2013). 
abstract (von Lewinski 2009: 124; Nand 2012). The language employed by the policymakers becomes "neither "familiar" nor "unfamiliar", an artefact neither of local culture, nor of regional or international institutions (Jolly 1996: 185; see also Riles 1998: 397). In Anthony Seeger's words, such a language looks at 'art' but not much at those who produce that art (personal communication, 12 March 2012).

Several legal commentators have been trying to engineer alternative proprietary paths and recommendations to bypass the perceived weaknesses and potential sites of conflict inherent in the development of sui generis legislation. Ownership of traditional knowledge in the sense used by sui generis legislation is not a customary concept. Well cognisant of the fragility of many customary institutions around the region, Miranda Forsyth has been evaluating a series of constructive alternative approaches, from a practical toolbox of regulatory strategies in place of the current proprietary rights approach (Forsyth 2013a) to cultural sustainability strategies urging a consideration of existing customary mechanisms (Forsyth 2015). In particular, after David Throsby (2010), she stresses that regulatory structures need to balance the objectives of supporting the interests of artists and custodians of cultural heritage today, and ensuring the continuation and evolution of local knowledge systems and traditional expressions of culture as a body of inspiration for future generations (Forsyth and Farran 2015: 13-14).

In the last decade, theoretical writing by several legal anthropologists has demonstrated the relevance of the social sciences and, in particular, anthropology to the articulation of the complexity of property relations (see Busse and Strang 2011: 2). Both legal anthropology and interdisciplinary scholarship on intellectual property have illustrated the law and society tenet that identities are forged in accommodation and in resistance to law, and that communities and localities are forged in relation to legal representations and their interpretations' (Coombe 2011a: 80-81).

As I examine in the following sections, it is in this climate of constraint on one side and innovation on the other that Fiji is continuing its journey to protect Indigenous Fijian (iTaukei) IP rights in their tangible and intangible cultural heritage via an ad hoc statutory law (Draft Legislation), and a National Cultural Policy (Draft Cultural Policy) designed to inform the Draft Legislation itself. More recently, anthropological analysis of policy and lawmaking, like its older sister legal anthropology, is allowing us to observe under which conditions fragments of culture and society 
are brought into new alignments with each other to create new social and semantic terrains and provide the rationale for 'regime change' (see Shore, Wright and Però 2016: 2).

\section{Have we been narrowing 'property' to mean 'ownership'?}

Pacific Island countries' demand for a policy informing domestic legislations to support the protection of their traditional knowledge and expressions of culture emerged in Fiji in April 1995 with the Suva Declaration, issued at the time the South Pacific Regional Consultation on Indigenous Peoples, Knowledge and Intellectual Property Rights was held in Suva. The Suva Declaration declared the right of indigenous peoples of the Pacific to self governance and independence of our lands, territories and resources as the basis for the preservation of indigenous peoples' knowledge' (Preamble). In addition to a hoary, at this point, criticism of the current IP protection system, the Suva Declaration also contains a plan that, although essentially concerned with the protection of local biological resources and calling for a moratorium on bioprospecting in the Pacific, is also designed to 'encourage chiefs, elders and community leaders to play a leadership role in the protection of indigenous peoples' knowledge and resources' (Suva Declaration 3.1), and 'strengthen the capacities of indigenous peoples to maintain their oral traditions, and encourage initiatives by indigenous peoples to record their knowledge in a permanent form according to their customary access procedures' (Suva Declaration 8.0).

As a result, four years later, in February 1999, UNESCO and the Secretariat of the Pacific Community (SPC) convened a 'Symposium on the Protection of Traditional Knowledge and Expressions of Traditional and Popular Indigenous Cultures in the Pacific Islands' in Noumea. The symposium brought together the representatives of 21 states and territories of the South Pacific region. It took stock of the different aspects of the protection of traditional knowledge and expressions of popular indigenous cultures in the Pacific Islands, and adopted a Final Declaration. The next year, the Pacific Island Economic Ministers supported the Pacific Islands Forum Secretariat (PIFS) in its work with the SPC in developing an integrated regional policy framework and model legislation 
for the protection of traditional knowledge in its relation to biodiversity, agriculture, ecological, medicinal and traditional expressions of culture, encouraging guidelines from the regional members.

The 2002 Regional Framework for the Protection of Traditional Knowledge and Expressions of Culture contains the Model Law for the Protection of Traditional Knowledge and Expressions of Culture (Model Law). The Model Law, an IP-based sui generis system creating new IP-like rights for intangible cultural heritage, is designed to legislate traditional and moral rights over traditional knowledge and expressions of culture that previously might have been regarded as part of the public domain. The Model Law is not an indigenous declaration. It provides a hybrid national and regional approach including enforceable sanctions. It establishes a regional legislative framework, but leaves matters of implementation to policymakers in accordance with their national laws and systems. The Model Law encourages the inclusion of customary law and traditional governance systems in national legislation over cultural property rights. It recognises that the traditional custodians should remain the primary decision makers regarding the use of their traditional knowledge and expressions of culture in accordance with their customary forms of protection.

In October 2003, the 32nd Session of the General Conference of UNESCO, 'considering the importance of the intangible cultural heritage as a mainspring of cultural diversity and a guarantee of sustainable development' (UNESCO 2003), adopted the Convention for the Safeguarding of the Intangible Cultural Heritage (Convention). Clearly, Article 12 (Inventories) and Article 13 (Other measures for safeguarding) of the Convention triggered a revival of tradition, leaving Pacific Island policymakers 'in between', in a sort of a chicken-and-egg paradox involving envisioning inventories, adopting a general policy aimed at promoting the function of the intangible cultural heritage in society, and eventually adopting appropriate legal, technical, administrative and financial measures aimed at establishing documentation institutions for the intangible cultural heritage.

The biggest problem both the Model Law and the Convention face is that the rhetoric of cultural ownership may give rise to 'absurd claims' (Comaroff and Comaroff 2009, cited in Coombe 2009: 406), particularly when contemporary social categories are deployed to make possessive assertions with respect to historical objects that long predate the identities 
of those claiming them (Appiah 2006, cited in Coombe 2009: 406). We are fundamentally misunderstanding the very concept of property if we focus primarily upon a western model of exclusive individual or corporate ownership. As Coombe and other legal scholars (see Carpenter, Katyal and Riley 2009) suggest, critics of cultural property wrongly conflate property with a narrow and fundamentalist paradigm of property that emphasises alienation, exclusivity and commodification.

In this direction, over the past two decades, we have witnessed a new and vital field of cultural rights norms and practices emerging in the shadows of cultural properties yet to be validated by formal systems of western law (Coombe 2009: 407). Cultural heritage policies, in particular on intangibles, have acquired a new social and political value in Fiji and Oceania. Undoubtedly, since the time of the 'Study on the Protection of the Cultural and Intellectual Property of Indigenous Peoples' (the Daes Report), ${ }^{12}$ a more nuanced international understanding of cultural property has developed. If 'cultural property can be distinguished from intellectual property by comparing the type of relationship that exists between a person and a commodity' (Attar, Aylwin and Coombe 2009: 318-19), then it often translates more into 'custodianship' than 'ownership'.

Elsewhere (Pigliasco 2009a, 2010, 2015), I have explained how in the case of Fijian firewalking (vilavilairevo) — today a signature brand statement of Fijian national culture 'owned' by the Naivilaqata bete (priestly clan) of the Sawau people of Beqa Island-custodianship operates outside the logic of 'possessive individualism' (Harrison 2000: 676) ${ }^{13}$ In other words, whereas western IP seeks to define products of human creativity that can be alienated from their creators, in Beqa among the Sawau, like in other traditional communities across the Pacific, the ownership of intangibles does not include the possibility of alienation, for 'property is actually a form of sociality' (Harrison 2000: 676; see also Miller 2001; Weiner 1992).

12 Erica-Irene Daes, academic, diplomat and United Nations expert, is best known for her almost 20 years of work with the United Nations Working Group on Indigenous Populations promoting the cause of the world's indigenous peoples. The report, produced in consultation with indigenous organisations, representatives of the First Peoples/First Nations and a wide variety of NGOs, was submitted to the United Nations Commission on Human Rights, Sub-Commission on Prevention of Discrimination and Protection of Minorities in 1993.

13 Harrison is borrowing the idea of 'possessive individualism' from Crawford Macpherson (1962). 
Hence, instead of narrowing property to mean ownership, Marilyn Strathern suggests we 'disappear' property, focusing our analysis without worrying about the meaning of property or whether the events we are investigating are really about property (Strathern 1984, cited in Verdery and Humphrey 2004: 11; see also Strathern 1999: 203). For a long time, the western idea of property rested on the establishment of a series of expectations. As Jeremy Bentham argued, 'Property is nothing but a basis of expectation ... It is not material, it is metaphysical; it is a mere conception of the mind' (1876: 111-12). Bentham also warns us that from the beginning any possession is very precarious, thus that property and law 'are born together, and die together' (ibid.: 113).

Eliesa Tuiloma was the principal legal officer with the Attorney General's Office in charge of the revisions of the Draft Legislation when I interviewed him in Suva in 2008. In the early version of the Draft Legislation that was sitting on his desk then, ideas of possessions, moral rights, caveats and redress were already embedded and inextricable, as became clear from our discussion. A prospective user of traditional knowledge or expressions of culture who wants to obtain the traditional owners' consent for a noncustomary use, Tuiloma explained to me, must first file an application specifying the ways in which a specific traditional knowledge (TK) or expression of culture (EC) will be used. The application will be published in a national newspaper, and will include instructions to interested persons as to how they may obtain a copy of it. Now, if a mataqali claims to be a traditional owner of the TK or EC in question, it has 28 days to advise the Cultural Authority. ${ }^{14}$ The traditional owners have certain 'moral rights', which include the right of attribution of authorship; the right not to have TK and EC falsely attributed to them; the right not to have their TK and EC used in insulting, derogatory or culturally or spiritually offensive ways; and the right to its divulgation and retraction. So, if the non-traditional user fails to make an application or uses the TK and EC in a way not described in the application or inconsistent with the traditional owners' moral rights, the traditional owners have a basis for a legal claim against that person-although, as Tuiloma pointed out,

14 Mataqali, often referred to as a 'subclan' (see Arno 1993: 9), is one of the most significant kin groups in Fiji and a major unit of social organisation throughout Fiji. It is equivalent to a landholding entity where all members have proprietary rights to an area of the land (ibid.; Nayacakalou 1975: 165; Ravuvu 1987: 17; Tomlinson 2009: 34). 
nothing would keep the traditional owners from attempting to resolve a dispute through alternative procedures, or customary law and practices (Eliesa Tuiloma interview, 5 June 2008).

From more recent interviews I had with Fiji policymakers in March 2013, it seems these ideas will reappear, elaborated even further, in the Cultural Policy. Fiji's Cultural Policy is in the process of redrafting its norms, in particular engineering proprietary rights to be vested in the community, individuals or the Cultural Authority, envisioned by the Model Law as a mediator between prospective users of Fijian TK and EC and traditional knowledge holders. The ambiguous term 'community', often seen as a 'convenient conceptual haven' (Forsyth 2013a: 1; see also Coombe and Weiss 2015), ${ }^{15}$ has been gradually expanded to include various legal entities, such as an association, a legal representative, a trustee, a corporation or a government body established by the community on behalf of the community and in whom the exercise of communal rights in traditional knowledge and expressions of culture would be vested; it can even refer to an individual who meets specific criteria, such as an indigenous person who is connected to a local community and who has received knowledge through intergenerational means. Lastly, the Cultural Authority—an entity stipulated in the Model Law and promptly inserted in the early resolutions of the Draft Legislation-would assume ownership of orphaned or unidentifiable traditional knowledge and expressions of culture. ${ }^{16}$

15 'Community is important because it is typically seen as a locus of knowledge; a site of regulation and management; a source of identity and a repository of tradition; the embodiment of various institutions (say, property rights), which necessarily turn on questions of representation, power, authority, governance, and accountability; an object of state control; and a theatre of resistance and struggle (of social movements and potentially of alternative visions of development)' (Watts 2000: 37). 16 The 5th Draft of the Legislation of September 2005 introduced the idea of a Cultural Authority consisting of a chairperson and four other members, appointed for a term of up to three years and eligible for reappointment. The originally drafted functions of the Cultural Authority were to receive and process applications; to monitor compliance with authorised user agreements and to advise traditional owners of any breaches of such agreements; to develop standard terms and conditions for authorised user agreements; to provide training and education programs for traditional owners and users of traditional knowledge or expressions of culture; to develop a code of ethics in relation to use of traditional knowledge and expressions of culture; to maintain a record of traditional owners of knowledge and expressions of culture (Pigliasco 2007: 392). 
The UNESCO's Intangible Heritage Convention, adopted in 2003, entered 'into force' in 2006. ${ }^{17}$ Recently, Janet Blake commented that the Convention broke new ground, introducing new terminology and new definitions of existing terms, and requiring a reexamination of some approaches to international and national lawmaking and policymaking by creating a new paradigm for identifying and safeguarding intangible cultural heritage that shifted the focus of significance (2014: 291). Other commentators like Chiara Bortolotto instead juxtapose the domestication of the UNESCO Convention-and in particular its inventorial section from state members - to the quintessential symbol of cultural homogenisation, McDonald's, and its highly standardised procedures (2012: 277).

Fijian policymakers realised that a total reliance on both the Model Law and the Convention would be insufficient and inconvenient for resolving core issues of identification of ownership, benefit sharing and compensation, to name a few. Instead of allowing lawyer consultants and policymakers to decide these issues through debates based on hot air, achieving what Annelise Riles (2006: 194) would call the "infinity" of consultations', the policymakers introduced the idea of first having in place an ad hoc, Fijian language database of Traditional Knowledge and Expressions of Culture, shifting the focus from economy to social capital. In 2004, the Institute of Fijian Language and Culture (recently renamed iTaukei Institute of Language and Culture $)^{18}$ launched the ambitious $N a$ ituvatuva ni kilaka itaukei kei na kena matanataki, the national inventory of indigenous Fijian traditional knowledge and expressions of culture currently referred to as the Cultural Mapping Programme. From its inception, cultural mapping

17 According to Article 34 of the Convention, it entered into force on 20 April 2006 for those States that had deposited their respective instruments of ratification, acceptance, approval or accession on or before 20 January 2006. It shall enter into force with respect to any other State three months after the deposit by that State of its instrument of ratification, acceptance, approval or accession. Currently, the Convention lists 165 State members, including Fiji, which ratified it on 19 January 2010.

18 On 30 June 2010, the Cabinet approved a Ministry of Fijian Affairs Decree that replaced the words 'Fijian' or 'indigenous' or 'indigenous Fijian' with the word 'iTaukei' in all written laws and all official documentation and public offices when referring to the original and native settlers of Fiji. 
in Fiji promised to be more than just creating an inventory of cultural sites, cultural rituals and traditional knowledge, as its process involves consultation, assessment and information gathering. ${ }^{19}$

As in the case of the Solomon Islands, as presented by Lawrence Foana'ota and Geoffrey White, the project obviously had to face and challenge the continuing influence of European visions of culture as premodern "tradition" signified by objects and activities to be collected and preserved' (2011: 291; see also Pigliasco and Lipp 2011). Designed as a collaborative process involving face-to-face, culturally protocolled dialogues and interviews between stakeholders and trained indigenous Fijian researchers, the project, regardless of Fiji's political turmoil, remained on track. With over 1,700 villages visited, and all but one of Fiji's 14 provinces culturally mapped, the iTaukei Institute of Language and Culture research teams are now in the process of returning to the first province mapped, Namosi, to update information gathered in the last 10 years.

Carried out in three phases-'pilot tests', 'focal collection of cultural data' and the 'assessment and input of final data' - the Cultural Mapping Programme initially planned to complete the project in three years (2004-2007). In the meantime, according to the Institute's former director, Pita Tagicakirewa, nine more years have been added for the 'refinement of data collection methodologies, the improvement in digital equipment use and storage of data, the digitisation of archived materials, the recruitment of additional field officers, the refresher training programs and the improvement of the Fijian language database of Traditional

19 Paragraph 5.2.3 'Nature and Objectives of National Inventory' of the training manual for the 'May 2005 Training Workshop on Field Research Methodology Designed for Cultural Mapping Field Officers' specifies that:

Designated in Fijian as na ituvatuva ni kilaka itaukei kei na kena matanataki, the national inventory project envisages the diverse traditional knowledge and cultural expressions that explicitly exists within the culture of the iTaukei (native Fijians). For the 14 provinces that compose Fiji, each has its own distinct local knowledge and cultural system, which characterise their uniqueness. However, with globalisation and rapid development in information technology, traditional expressions in Fiji are continually being exploited for commercial purposes, and on the verge of being replaced completely by a massive culture of modernism. Hence, the inventory is/was established with the following issues in mind: (i) the preservation and safeguarding of tangible and intangible cultural heritage; (ii) the promotion of cultural diversity; (iii) the respect for cultural rights; and (iv) the promotion of tradition-based creativity and innovation as ingredients of sustainable economic development. 
Knowledge and Expressions of Culture housed at the iTaukei Institute of Language and Culture' (Pita Tagicakirewa, personal communication, 28 March 2013). ${ }^{20}$

\section{Cultural policy and cultural industries: An oxymoron?}

Recently, both Palau and the Cook Islands have completed their national cultural policies and enacted traditional knowledge and expressions of culture laws, while in Kiribati, Solomon Islands, Papua New Guinea and Vanuatu cultural policies and statutory laws have been submitted for peer reviewing and comments are getting incorporated in the final drafts. In the case of the Solomon Islands, Foana'ota and White observe how national cultural practices from the colonial period to the present 'have taken place in an isolated, fragmented environment with few connections to governmental institutions that might sustain them. Hence, the urgent need for some form of cultural policy' (2011: 291). Clive Gray would probably identify the motives behind the Solomon Islands and other Pacific Island governments' involvement with cultural policy as ranging from the promotion of 'national glory' to the maintenance of 'order and control' (2007: 204).

In Fiji, the situation is that after 19 drafts of the Draft Legislation, the acquired language mediated by international policies, recommendations, workshops, guidelines and action plans induced the working group to make a legislative U-turn in order to first draft a policy to serve as a guideline for the Draft Legislation. The urgency of this move was also underlined in June 2014 by Sipiriano Nemani, Director of the Fiji Museum, and former Principal Policy Convention Officer at the Department of Heritage and Arts, in an interview on Fiji One Television, 'Because our activities in the culture sector in Fiji is spread all over the place, there are often duplication of functions and some of our legislation are very archaic and old and need to be revised' (see Datt 2014).

20 The choice of adopting only the standard Fijian language ( $\mathrm{Na}$ Vosa Vakaviti) in such an overtly multiethnic Pacific Island nation as Fiji has been enforced and defended since 2004 to ensure maximum confidentiality of the information stored. Vanuatu, the first Pacific Island nation to complete its 'cultural mapping', adopted a trilingual database for the Vanuatu Kaljoral Senta (Vanuatu Cultural Centre) (see Geismar and Mohns 2011). 
Warning us against being taken in by 'surface appearances', Gray emphasises how cultural policy does not operate in splendid isolation from broader societal pressures (2007: 205). Cultural policies are the result of conscious choices made by political actors. Andrew Arno observes that 'policy and rule are a linked discursive pair, and neither makes sense without the other' (2009: 153). Fijian policymakers realised the necessity of a policy to inform the legislative drafting process after setting up a body of self-contained rules and formulating some amendments based on the suggestions of international consultants, the Secretariat of the Pacific Community's guidelines, Panama's legislation on collective rights of indigenous communities and the Peruvian laws protecting the collective knowledge of indigenous peoples. ${ }^{21}$ Last but not least, they also considered the work and suggestions of Unaisi Nabobo-Baba (2006) on developing a policy to ensure that $i$ Taukei knowledge and epistemology receives greater recognition.

Ten years after its inception, and with a conspicuous number of policy practitioners and consultants involved, Fiji's National Cultural Policy is in the process of being rewritten and reframed. ${ }^{22}$

Applying additional intellectual pressure, the 2011 Melanesian Spearhead Group (MSG) Framework Treaty on Traditional Knowledge and Expressions of Culture is trying to get some attention through a different angle and political force. The Treaty was initially envisioned as a Melanesian strategy to bypass the complexities surrounding national legislations and to strengthen trade, cooperation and the exchange of Melanesian cultures and Melanesian traditions and values among its member countries of Fiji, Papua New Guinea, New Caledonia, Solomon Islands and Vanuatu. The MSG legislative intent appears, however, to be one size fits all—and

21 The working group initially outlining Fiji's National Cultural Policy was composed of members from the iTaukei Institute of Language and Culture, the Department of Culture and Heritage, the Attorney General's Office and the Ministry of Fijian Affairs, assisted by Eliesa Tuiloma, former Principal Legal Officer and drafter of the legislation, and Gail Olsson, an independent consultant for the TradeCom Programme financed by the European Development Fund, which is currently financially supporting the legislation.

22 As this chapter goes to print, there is clear indication of an imminent motion coming from Fiji's Parliament of the Republic of Fiji to accelerate the approval process of the Draft Legislation and proceed to sign and promulgate the bill protecting Indigenous Fijian traditional knowledge and expressions of culture, while the Draft Policy's approval necessitates a swifter pre-legislative scrutiny at Cabinet level. 
only Melanesian—when we have MSG member states like Fiji developing a National Cultural Policy first in the effort to establish relationships at both regional and international levels in the cultural heritage sector.

Fijis Draft Cultural Policy appears to have been more concerned with reviving Fiji's economies and, more recently, redirecting its support of the cultural industries by supporting the so called MSME (micro, small and medium enterprise) sector, as well as emphasising economic empowerment of iTaukei, youth in general and young women in particular. The Draft Cultural Policy is basically designed to allow the creation of new opportunities for income and employment while supporting artistic and cultural creativity. For example, the Draft Cultural Policy includes recommendations for developing and making available micro-credit, advisory services and training for developing products and services that involve traditional knowledge and expressions of culture. Clearly emerging from the spirit of the policy are the vital role of customary law and protocols and their complex relationship with intellectual property rights and existing regulations (i.e. copyrights, trademarks, patents, designs and geographical indications) and, ultimately, with the Cultural Mapping Programme and related database, which are aimed at identifying the small communities that may be the holders of traditional knowledge or stewards of heritage sites (Pigliasco 2011).

Meeting all the goals that are proposed in the Draft Cultural Policy, in particular those aimed at establishing a viable framework for the use of traditional knowledge and expressions of culture in Fiji, will be, obviously, quite challenging. As of 2013, the Draft Cultural Policy indicated a mandatory connection with customary law and protocols as well as national policies and laws on copyright and related matters. As noted earlier in this chapter, the Draft Cultural Policy is in the process of being rewritten to meet some new objectives: foremost, raising awareness of the importance of respecting, understanding and protecting $i$ Tankei values, language, cultural expressions and traditional knowledge through educational curricula and media; ${ }^{23}$ next, paying particular attention to youth, including assistance and training to support iTaukei cultural practitioners in the tourism industries and in local, regional

23 In its $2013 \mathrm{draft}$, the Cultural Policy explicitly promised to have been developed in consultation with Fiji's $i$ Taukei communities across its 14 provinces since the very inception of the cultural heritage awareness movement in 2004, reflecting the commitment of both the policymakers and iTaukei to safeguard, protect and promote their traditional knowledge and expressions of culture. The respect for the moral and spiritual integrity of $i$ Tauke $i$ traditional knowledge and expressions of culture includes 
and international festivals; and, lastly, rebuilding confidence around the creation of a label of authenticity and a system to mark products made by iTaukei artists and craftspeople, a sort of 'Brand Fiji', with the support of the Ministry of Tourism to provide new markets for iTankei cultural products.

The Fijian policymakers I interviewed pointed out that the iTaukei must be ready to negotiate both traditional and non-traditional ways of living and knowing. Increasing contact with other cultures has brought alternative ideas and philosophies of life, and this has affected traditional value systems. The results include pressure to adopt individualistic ideals over communal ones, growing migration from villages to cities for education and work, weakening social structures and loss of cultural knowledge and information. ${ }^{24}$

Several questions mediated through workshops and regional meetings and in particular the 2006 SPC Guidelines ${ }^{25}$ seem also to be addressed by the Draft Cultural Policy: the subject matter of protection, the criteria for protection, determination of ownership and of the beneficiaries, exceptions and limitations regarding rights, how rights will be managed, how rights will be enforced, what processes can be used for dispute resolution, what the relationship is with existing IP protection and how international and regional protection will be addressed.

The Draft Cultural Policy appears to find additional inspiration in the Revised Draft Provisions for the Protection of Traditional Cultural Expressions: Policy and Objectives and Core Principles (Draft Provisions) elaborated in 2006 by WIPO (World Intellectual Property Organization) (WIPO 2006). Overall, the Draft Cultural Policy is quite ambitious in its approach and reach, and in particular in its understanding of the

censuring the collection and publication of traditional stories without consent or proper attribution, or in a culturally offensive manner, as for example in the frequent appropriations of the itukuni and italanoa of Dakuwaqa, the Fijian ancestral shark god, and other legends as marketing tools on tourist websites.

24 In its 2013 draft, the policy was still finding the wording for iTaukeis cultural systems and iTaukei's understanding of the world based on three kinds of knowledge: kila ni vuravura (knowledge of the empirical world), kila ni bula vakaveiwekani kei naitovo (knowledge of the social order and sociocultural relationships) and kila ni bula vakayalo (knowledge of the cosmos).

25 On 28 April 2009, the Secretariat of the Pacific Community made available on its website the 2006 guidelines designed to assist policymakers in Pacific communities in the development of national legislation for the protection of traditional knowledge and expressions of culture based on the Pacific Model Law 2002. Online: www.spc.int/hdp/index.php?option=com_docman\&task=cat_ view\&gid=37\&Itemid=44 (accessed 28 January 2016). 
role of intellectual property rights (IPRs) in mediating between local knowledge and the global marketplace, in its effort to recognise possible misappropriations and misuses. Most notably, the Draft Cultural Policy recognises that the term 'owners' is not necessarily useful or appropriate to refer to iTaukei communities when the goal is to focus on the group's cultural capital and its sustenance rather than its potential exploitation in the marketplace. As discussed earlier, 'ownership' may trigger strife and conflict within communities.

The Draft Cultural Policy's most innovative approach in establishing guidelines regulating the integrity of Fijian traditional knowledge and expressions of culture is perhaps the inclusion of documentation of past misuse and misappropriation. Among the examples of misuse and misappropriation, the Draft Cultural Policy mentions the unauthorised reproduction of traditional masi designs, as well as the misappropriation and misuse of images commonly available in the public domain of 'sacred rituals' like the vilavilairevo (firewalking ceremony). ${ }^{26}$

In this sense, the Fijian language database of Traditional Knowledge and Expressions of Culture becomes an arm of the Draft Cultural Policy and subsequent Draft Legislation. The database's information will be needed to enforce and expand the protection of intellectual property rights, arrange benefit-sharing among the traditional custodian communities, and control access to the traditional knowledge and expressions of culture in the cultural database itself by both research and educational institutions, as well as by private sector entities.

While the Database of Traditional Knowledge and Expressions of Culture and the application of customary law and practices remains a priority of the Draft Cultural Policy, the development of a sui generis legislation to protect traditional knowledge and expressions of culture still represents one of its major objectives and obstacles. A delicate point will be the relationship of the Draft Legislation with existing intellectual property

26 In January 2005, the iTaukei Institute of Language and Culture (formerly, Institute of Fijian Language and Culture) supported the $A$ ituvatuva ni vakadidike e sawau (the Sawau Project), a multimedia DVD project narrated by the Sawau people of Beqa (Hennessy 2009; Pigliasco 2009a; Pigliasco and Colatanavanua 2005), within the pilot project's part of Fiji's Cultural Mapping Programme, and Cultural Mapping Traditional Knowledge Database and Server, which was officially launched in May 2005. 
rights to ensure consistency and complementarity with them. ${ }^{27}$ According to von Lewinski, commenting about the Model Law, this is 'nothing new'. These overlaps are expected:

where an existing intellectual property right applies in an individual case, the specific folklore protection may apply cumulatively. Such an overlap of protection is justified on the grounds that both the purposes of protection and the conditions thereof differ in the case of each IP or specific folklore right. Accordingly, these systems of protection remain consistent in themselves (von Lewinski 2009: 123).

Another delicate point, the solution of which is yet undisclosed, appears from early drafts of the legislation: the establishment of a Cultural Authority, which may be integrated into an existing institution, and whose core responsibilities would include implementing and coordinating policy and prospective legislation, monitoring infringements and administering rights and eventual disputes. The initial idea was to replace the too broad institution of a Cultural Authority with an Indigenous Intellectual Property Rights Authority. Back in 2008, Tuiloma thought that any 'authority' in charge of cross-checking and pursuing the relevant traditional knowledge and expressions of culture should not be working in isolation from Fiji's copyright and patenting office copyright structure, which may be able to provide support for recognising their existence or previous registration (Eliesa Tuiloma, interview, 5 June 2008). This idea of centralising the various functions of intellectual property in Fiji reappeared when the Draft Cultural Policy was moving towards completion, with the creation in 2011 of a new entity, the Fiji Intellectual Property Office (FIPO), capable of patenting and putting to better use intellectual property or traditional knowledge.

Believing that Fiji's intellectual property laws continue to be a relic of the colonial era, Fiji's Attorney General Aiyaz Sayed-Khaiyum argues that for these reasons Fijis present intellectual property regime does not fully comply with international treaty obligations. Because of the lack of effective coordination among various government departments, Sayed-Khaiyum believes that laws, policies and practices with respect to

27 These include the Copyright Act 1999, Trademarks Act 1933, Patents Act 1879, Merchandise Marks Act 1933, Industry Emblem Act 1973 and the United Kingdom Design Protection Act 1936. According to Salvin Nand (2012: 56), the relationships will be quite difficult to ascertain, for with the exception of the Copyright Act these legislations were formulated and enacted without any policy consideration given to traditional knowledge and expressions of culture. 
intellectual property are not effectively enforced. FIPO is thus becoming a one-stop shop for anything related to copyright and other related rights, trademarks, patents, designs, merchandise marks, geographical indications and also traditional knowledge and expressions of culture. A concern is that, with the prospective development of a label of authenticity and the creation of 'Brand Fiji' by the Ministry of Tourism, along with the associated marketing of iTaukei culture, FIPO may become a cul-de-sac, clogging the office of the solicitor-general and permanent secretary for justice, which, with WIPO, is responsible for FIPO's administration. ${ }^{28}$

For example, in the Fiji Airways masi case, in the absence of legislation to protect the masi makers, it will be very interesting to see how the case will be evaluated, and by whom. Na Noda Masi's e-petition ${ }^{29}$ against the trademarking of the 15 masi motifs was submitted to the Registrar of Trademarks office at Suvavou House in Suva-where FIPO is also housed-accompanied by an independent legal opinion drafted by legal scholar Miranda Forsyth (2013b), a brief on anthropological evidence on the 15 motifs compiled by Cresantia Frances Koya Vaka uta (2013) and a list of recommended consultants who would provide testimony against the trademarking of these kesakesa and any other form of indigenous collective knowledge. ${ }^{30}$ The masi case also has a potential intersection with the

28 The global IP treaties that Fiji is party to include the Berne Convention for the Protection of Literary and Artistic Works, the Rome Convention for the Protection of Performers, Producers of Phonograms and Broadcasting Organizations and the Trade-Related Aspects of Intellectual Property Rights Agreement. Fiji is also party to a range of traditional knowledge and expressions of culture related treaties such as the UNESCO World Heritage Convention, the UNESCO Convention for the Safeguarding of the Intangible Cultural Heritage, ILO 169 on Indigenous and Tribal Peoples, the Convention on Biological Diversity and the International Undertaking for Plant Genetic Resources. At the regional level, Fiji is a member of the Pacific Islands Forum Secretariat (PIFS), the Secretariat of the Pacific Community (SPC) and the Secretariat of the Pacific Regional Environment Programme (SPREP), which have assisted in the development of norm-setting guidelines for traditional knowledge and expressions of culture that have influenced the Cultural Policy, while at the subregional level, it is a member of the Melanesian Spearhead Group, which promotes cultural solidarity within the countries of Melanesia.

29 See 'Petition to Appeal to stop Air Pacific trademarking 15 distinct masi motifs', Change.org. Online: www.change.org/petitions/prime-minister-voreqe-bainimarama-appeal-to-stop-air-pacifictrademarking-15-distinct-masi-motifs (accessed 28 January 2016).

30 Upon an extension granted by the Registrar (Solicitor General) of Trademarks Office, on 24 September 2013, Fiji Airways lawyers filed counter statements to the opposition presented by the iTaukei Trust Fund Board, the Fiji Museum, Cresantia Frances Koya Vaka'uta, Seini Nabou, Akaninsi Kedravate and the Institute of Indigenous Studies against the airline company. On the same day, Na Noda Masi posted on Facebook the following statement:

According to Mr. Seeto from the Registrar of Trademarks office, all five objectors will then be invited by the Registrar (Solicitor General) to respond to the counter statement before the Registrar decides whether to grant the trademark application to Fiji Airways, or to reject 
recent emphasis on culture industries. On this topic, the instrumentality of both the Draft Cultural Policy and the Draft Legislation are even more straightforward.

Several policy scholars and commentators believe that both 'culture' and the 'arts' are instrumental tools for the attainment of non-cultural goals (Gray 2007). ${ }^{31}$ According to Andy C. Pratt, culture industries and cultural policy are 'oxymorons': 'One reason for the ambivalent position that the cultural industries occupy is that they are commercially oriented and commonly regarded as mass or low culture. Yet, they are situated under the umbrella of "cultural policy" (Pratt 2005: 31). Coombe observes that 'there is little doubt that many new cultural collectivities making possessive claims do so as market actors for economic purposes' (Coombe 2011a: 80; see also Comaroff and Comaroff 2009). In The Economics of Cultural Policy, Throsby observes that, over recent years, the evolution of cultural policy has at times been characterised as a 'transformation into an arm of economic policy', which 'may appear somewhat far-fetched, seeming to subordinate the lofty purposes of culture to the sordid demands of the marketplace, a final realisation of the Adorno/Horkheimer nightmare of the commodification of culture' (2010: 6).

David Hesmondhalgh and Andy C. Pratt observe that the boom in interest in the idea of the 'cultural industries' (or creative industries) in academic and policymaking circles raises poignant questions about shifting boundaries between culture and economics, and between art and commerce. They ask a straightforward question: 'What lies behind such policies?' (Hesmondhalgh and Pratt 2005: 1). The 2012 Secretariat of the Pacific Community's Regional Culture Strategy: Investing in Pacific Cultures, 2010-2020, which is focused on investing in Pacific cultures in the period of 2010-2020, promotes Pacific cultural industries as tools for development and to create opportunities for the Pacific Island nations: 'cultural industries offer potential to address issues of poverty

it. Once the Registrar decides, that decision can be appealed to the Fiji High Court. So we are still at the exchanging paper stage folks, not yet at courtroom stage smile emoticon hang in there, we're following the legal process set out in the Trademarks Act with our objection.

The day after, 25 September 2013, Na Noda Masi posted on Facebook its last update so far: 'The counter statement does not specifically answer the assertions we have made that these motifs are ancient and existed long before Air Pacific and Fiji Airways and that they were documented, proving that they were not created by Fiji Airways in the last year alone'.

31 A Regional Consultation on the Cultural Industries, held in Fiji in 2010, was jointly organised by the Secretariat of the Pacific Community and the Pacific Islands Forum Secretariat, and funded by the European Union (see Huffer 2010). 
and sustainability through increased income generation by communities, cultural practitioners and entrepreneurs. They are recognised internationally as a growth area, one that enables people to express themselves creatively, with dignity and on their own terms' (Council of Pacific Arts and Culture and the Secretariat of the Pacific Community 2012: 14).

In Weaving Intellectual Property Policy in Small Island Developing States, Miranda Forsyth and Sue Farran (2015) challenge the assumption that intellectual property rights will automatically promote 'cultural industries', and caution that they may have 'unanticipated negative consequences' (Forsyth and Farran 2015; see also Forsyth 2015). ${ }^{32}$ The point becomes even more clear in regard to the recent overemphasis on culture industries in policy talks at local and regional levels (among others see Huffer 2010; Teaiwa 2012; Teaiwa and Mercer 2011; Tuiloma 2012). Cultural industries without adequate customary support may risk ignoring indigenous epistemologies and following the spiral path, as mentioned by Throsby (2010), where enlightenment conflates with mass deception satisfied only by the products of capitalism.

This shift and expansion in cultural industries' focus has actually been made possible by, among other developments, the European Union agreement that granted $€ 713,474$ (the equivalent of about $\mathrm{FJ} \$ 2$ million) to the Secretariat of the Pacific Community for a project to strengthen the cultural sector in six Pacific Island countries: the Federated States of Micronesia, Palau, Solomon Islands, Tonga, Tuvalu and Vanuatu. ${ }^{33}$ The project targets four specific but complementary and mutually supporting areas of the cultural sector: policy development, cultural industries promotion, cultural heritage preservation and exchanges between Pacific and Caribbean museums.

32 The recent and enigmatic UNESCO 'Florence Declaration' of 4 October 2014 recognises that: The full potential of the cultural industries at the core of the creative economy must be harnessed to stimulate innovation for economic growth, full and productive employment and decent work for all. When cultural and creative industries become part of overall growth and development strategies, they have proven to contribute to the revitalization of national economies, generate green employment, stimulate local development and foster creativity. Evidence shows that they provide new local development pathways that build on existing skills and knowledge (UNESCO 2014).

33 This SPC project is called 'Structuring the cultural sector in the Pacific for improved human development' and resulted from a call for proposals for projects under the 'Investing in People' Thematic Programme. Online: www.spc.int/hdp/index.php?option=com_content\&task=view\&id= 89\&lang=french (accessed 28 January 2016). 
The way Fiji and other Pacific Island nations have, in Sahlins's (2005: 6) and also Jolly's (2005: 138) words, 'indigenized the power of the foreign' in their policies, as well, the ways that they have envisioned innovations in their traditions and customs, is quite remarkable. However, it's nothing actually new from a legal historical perspective. The 'indigefication' of legal concepts is well known in western jurisprudence since the incorporation of Roman law into German folk law. The Tongan kato alu (traditional Tongan basket) becomes, for instance, a framework for outlining the important domains of Tongan culture, showing how indigenous epistemology, domains of tangible and intangible cultural heritage and cultural industries could be evoked and wrapped together in the different layers of the basket (Fua, Tuita, Kanongata'a and Fuko 2011: 10).

Nevertheless, and not to underestimate China's and other Pacific Rim countries' considerable and growing influence and economic competition in Oceania, behind these remarkably culturally sensitive policies may actually lie the negotiation of exclusive/joint fishing and deep-sea mineral and energy exploration rights, among others, of far greater value to the EU than the millions donated to the Pacific region. ${ }^{34}$ These recent neocolonial forms of control over the trade routes, and political-financial alliances in Fiji and other Pacific Island nations, suggest that policymakers have to carefully evaluate and balance the power differentials existing in the field of cultural policymaking and the regulation of the cultural industries (see Hesmondhalgh and Pratt 2005: 11). While cultural policies and cultural industries might stress local priorities, needs and place-based cultural values, their activities are shaped by the activities of external actors, including states, corporations, NGOs, UN bodies and development aid institutions. All have particular interests in 'empowering communities as entrepreneurs, owners, stewards, or custodians of what are perceived to be scarce and endangered forms of knowledge' (Coombe 2011a: 79, 93).

34 The European Union is a major donor to Pacific ACP countries. The African, Caribbean and Pacific Group of States (ACP) was created by the Georgetown Agreement in 1975. Since 1975, the EU has provided the Pacific ACP with a total of $€ 194$ million for regional projects. This is in addition to over $€ 2$ billion provided to Pacific ACP countries bilaterally over the same period. Currently, there are 15 members of the Pacific ACP Group. The eight original signatories are: Fiji, Tonga, Samoa, Tuvalu, Kiribati, Vanuatu, Papua New Guinea and Solomon Islands. In 2000, six new members joined: Cook Islands, Federated States of Micronesia, Republic of the Marshall Islands, Nauru, Niue and Palau. Finally, in May 2003, Timor Leste became the 15th member to join. See Pacific Islands Regional Secretariat n.d. 
An update on cultural industries in Fiji, ironically clairvoyant of the recent Fiji Airways masi case, was offered at a talk given at the Conference on Creativity, Innovation, Access to Knowledge and Development at The Australian National University in Canberra in 2012 by Eliesa Tuiloma, the former legal officer and one of the architects of both the Draft Cultural Policy and Draft Legislation, 'emigree consultant' in the Republic of Nauru, and more recently on the staff of the Permanent Mission of the Republic of Fiji to the United Nations in New York.

Tuiloma well recognises the opportunities and limits of the creative industry. While creativity and innovation emerging from traditional knowledge and expressions of culture are the raw materials for the creative industry in Oceanic countries, among the current constraints he recognises are uncertainty about Fijis political and social stability; current policy and legislative deficiencies on traditional knowledge and expressions of culture; inadequate intellectual property legislation, registration systems and enforcement; institutional bureaucracy; high operational costs; and insufficient access to venture capital, low-interest financing, grant funding and markets. ${ }^{35}$ His thoughts easily translate from legalese into something like 'don't count your chickens before they're hatched'. How can we promote cultural industries if we are unable to protect our cultural rights in our own country first?

\section{Conclusion: And the vanua?}

Echoing education scholar Unaisi Nabobo-Baba's statement that 'individualism for its own sake is abhorred' (2006: 44), the energetic late Fijian intellectual Ropate Qalo claims that the whole idea of 'ownership' in Pacific Island society is repulsive. Somebody, however, is clearly taking advantage of this. Qalo argue:

the lack of a coherent voice to promote Pacific epistemology means that it is discounted, particularly when it comes to policymaking. Although there are many local institutions that are (partially) derived from local customs, they have so far failed to adequately promote Pacific life principles (Huffer and Qalo 2004: 108).

35 PowerPoint presentation given at the Conference on Creativity, Innovation, Access to Knowledge and Development, held at The Australian National University, Canberra, 22-23 September 2012. 
A decade after Qalo's statement, it is yet to be verified if Pacific Island policymakers will be able to respectfully indigenise the legislative approach to putting intellectual property regimes to work and rendering autochthonous cultural identities and epistemologies in the language of copyrights, trademarks, patents, industrial design rights and cultural and creative industries (see Comaroff and Comaroff 2009: 56). In the meantime, more cultural policies are emerging in Fiji, in Melanesia and beyond, and more glossy pamphlets and 'handbooks' are generated in workshops, meetings and conferences by regional intergovernmental organisations and agencies. At the same time, more economic resources related to the very social and cultural capital that both policies and regional and international intergovernmental organisations are trying to safeguard and implement are traded quid pro quo and exploited in exchange.

I have elsewhere described the strenuous forward-thinking work of Fijian cultural heritage connoisseur and policymaker Sipiriano Nemani. He has been emphasising for years that while both the Draft Legislation and its Draft Cultural Policy are instruments designed to bring awareness to the grassroots, the heritage custodians:

no government policy, no organised workshop, no financial assistance can help the indigenous community in Fiji elevate its traditional values and identity. All is vested with the vanua and those at the helm of traditional leadership to proactively pursue and reinforce to members of the vanua the importance of maintaining key customs (Nemani cited in Pigliasco 2011:325).

In other words, it is the vanua that is expected to take up the initiative to ensure that their intangible heritage is safeguarded and continues to evolve. It is the vanua that inevitably should emerge as a pivotal element in both the Draft Legislation and the Draft Cultural Policy.

Matt Tomlinson (2014: 122) explains that the vanua, considered a divine gift that God gave exclusively to indigenous Fijians, became the political emblem that mobilised popular support for the coups of 1987 and 2000. In the wake of Fiji's coups, which have brought ethnic tensions, fiscal deficit, deregulation and displacement of Fijian people, Tomlinson and many non-Fijian anthropologists have felt it necessary to analyse transformations in understandings of the vanua (Brison 2007; Kaplan 2011; Ryle 2010; Tomlinson 2014: 142). 
Before I left Suva in March 2013, Ropate Qalo shared some thoughts about the Fiji Airways masi case with me. Qalo firmly believes that all Fijians have to do is go back to their vanua, while legislators should keep conducting theoretical and pragmatic research into Pacific customary laws, values and worldviews to articulate the contemporary complexity of property relations of the vanua and within the vanua (Ropate Qalo, personal communication, 25 March 2013). In a sagacious commentary that appeared in the Fiji Times Online exactly one year before he passed away, Qalo places Fiji Airways in his 'eponymous power elite of Fiji' list, eponymous power referring to 'the interlocking interests of elites from three key aspects of society-politics, corporations (or economy), and the military-and how they had coalesced into one tightly knit power centre that worked to reinforce and steward their political and economic interests' (Qalo 2015).

Sadly, it is too late to ask Ropate Qalo to shed some light on the transformations in understandings of the role of the vanua in Fijis contemporary nomenclature. The risk I see is that heritage regimes and related instruments may be mystifying or misrepresenting the social dynamics of the vanua, neglecting actual differences in the interests and internal relations of power. In these heritage regimes and transnational processes of legal and political articulation, communities, as in the case of the Fijian vanua, are in important ways 'imagined', and traditions are often invented as innovative and generative foundations for investment, planning and development (see Coombe 2011a: 79, 2011b: 106; Coombe and Weiss 2015: 48). Legal scholar Rosemary Coombe has clearly exemplified in her corpus of work how these communities empowered as heritage regimes through the recognition of their traditional knowledge and cultural expressions are often situated at the intersection of the old regimes of power and attachment, emerging forms of governmentality and new imaginaries of social justice. Despite the emphasis placed on grassroots priorities, their activities are shaped by the activities of external factors, foreign institutions, global networks of influence and transnationally circulating policy instruments that have incorporated heritage norms into their own agendas (see Coombe 2011a: 79; Coombe and Baird 2015).

While perhaps more than just a sparkle of innovative thinking is permeating Fijian and Pacific Island epistemologies, as I have expressed before (Pigliasco 2012a), the path crossing the fields of ethics, politics and cultural policy appears yet slippery and tortuous in Fiji. It is possible 
in fact that the Fiji Airways masi case is one of those situations in which, echoing Strathern (2011), it is not appropriate to talk about property regimes, nor of heritage regimes, but of sharing, stealing and borrowing simultaneously, not forgetting the different genre the Fijian practice of kerekere has evolved into in the era of globalisation. From a 'begging system' as described in Hocart's (1929: 99-101) classic ethnography of the Lau Islands to the less pejorative 'demander une chose' (Hazelwood 1850 cited in Sahlins 1993: 855), to a wider mechanism permitting the soliciting of goods, services, resources and use rights, a sort of entreaty that cannot respectfully be denied. ${ }^{36}$ I wonder to what extent the 'tenets of the orthodoxy conceived and propagated by Fiji's protectionist colonial administration have become ineradicably absorbed into the Fijian national consciousness' (France 1969: 174), and 'culturally mediated by the indigenous people' (Sahlins 1993: 864), will be ingeminated or perhaps indigeficated in the new legal instruments designed to safeguard Fijian tradition.

\section{References}

Appiah, Kwame Anthony. 2006. Cosmopolitanism: Ethics in a World of Strangers. New York: W.W. Norton \& Co.

Arno, Andrew. 2009. Alarming Reports: Communicating Conflict in the Daily News. New York: Berghahn Books.

- 1993. The World of Talk on a Fijian Island: An Ethnography of Law and Communicative Causation. Norwood, NJ: Ablex.

Attar, Mohsen al, Nicole Aylwin and Rosemary J. Coombe. 2009. 'Indigenous cultural heritage rights in international human rights law'. In Protection of First Nations' Cultural Heritage: Laws, Policy, and Reform, ed. Catherine Bell and Robert Paterson, pp. 311-42. Vancouver: University of British Columbia Press.

36 While Thomas $(1992,1993)$ observes that in the first decade of colonial rule, several regulations and resolutions recommended the suppression of kerekere, Sahlins (1993: 854) observes that kerekere was so ubiquitous, multiform and commonly practised, as a cornerstone of Fijian life, that to attempt to legally interdict it was absurd. 
Ballacchino, Katia. 2012. 'Unity makes ... intangible heritage: Italy and network nomination'. In Heritage Regimes and the State, ed. Regina F. Bendix, Aditya Eggert and Arnika Peselmann, pp. 121-140. Göttingen Studies in Cultural Property Series 6. Göttingen: Universitätsverlag Göttingen.

Bell, Catherine and Robert Paterson (eds). 2008. Protection of First Nations Cultural Heritage: Laws, Policy, and Reform. Vancouver: University of British Columbia Press.

Bendix, Regina F., Aditya Eggert and Arnika Peselmann (eds). 2012. Heritage Regimes and the State. Göttingen Studies in Cultural Property Series 6. Göttingen: Universitatsverlag Göttingen.

Bentham, Jeremy. 1876. Theory of Legislation, translated from the French of É. Dumont by R. Hildreth. London: Trübner \& Co.

Berliner, David. 2012. 'The politics of nostalgia and loss in Luang Prabang (Lao PDR)'. In Routledge Handbook of Heritage in Asia, ed. Patrick Daly and Tim Winter, pp. 234-46. London: Routledge.

Blake, Janet. 2014. 'Seven years of implementing UNESCO's 2003 intangible heritage convention-honeymoon period or the "sevenyear itch"?' International Journal of Cultural Property 21(3): 291-304. doi.org/10.1017/S0940739114000113.

Bortolotto, Chiara. 2012. 'The French inventory of intangible cultural heritage: Domesticating a global paradigm into French heritage regime'. In Heritage Regimes and the State, ed. Regina F. Bendix, Aditya Eggert and Arnika Peselmann, pp. 265-82. Göttingen Studies in Cultural Property Series 6. Göttingen: Universitätsverlag Göttingen.

Brison, Karen J. 2007. Our Wealth Is Loving Each Other: Self and Society in Fiji. Lanham MD: Lexington Books.

Broccolini, Alessandra. 2012. 'Intangible cultural heritage scenarios within the bureaucratic Italian state'. In Heritage Regimes and the State, ed. Regina F. Bendix, Aditya Eggert and Arnika Peselmann, pp. 283-302. Göttingen Series in Cultural Property 6. Göttingen: Universitätsverlag Göttingen. 
Busse, Mark and Veronica Strang. 2011. 'Introduction: ownership and appropriation'. In Ownership and Appropriation, ed. Veronica Strang and Mark Busse, pp. 1-19. Oxford: Berg. doi.org/10.1484/m.mcseb.4.3002.

Carpenter, Kristen, Sonia Katyal and Angela Riley. 2009. 'In defence of property'. Yale Law Journal 118: 1022-125.

Comaroff, John L. and Jean Comaroff. 2009. Ethnicity, Inc. Chicago: University of Chicago Press. doi.org/10.7208/ chicago/9780226114736.001.0001.

Coombe, Rosemary J. 2012. 'Managing cultural heritage as neoliberal governmentality'. In Heritage Regimes and the State, ed. Regina F. Bendix, Aditya Eggert and Arnika Peselmann, pp. 375-87. Göttingen Studies in Cultural Property Series 6. Göttingen: Universitätsverlag Göttingen.

2011a. 'Cultural agencies: the legal construction of community subjects and their properties'. In Making and Unmaking Intellectual Property: Creative Production in Legal and Cultural Perspective, ed. M. Biagioli, P. Jaszi, and M. Woodmansee, pp. 79-98. Chicago: University of Chicago Press.

— 2011b. 'Possessing culture: political economies of community subjects and their properties'. In Ownership and Appropriation, ed. V. Strang and M. Busse, pp. 105-27. Oxford: Berg.

- 2009. "The expanding purview of cultural properties and their politics'. Annual Review of Law and Social Science 5: 393-412. doi. org/10.1146/annurev.lawsocsci.093008.131448.

Coombe, Rosemary J. and M. Baird. 2015. 'The limits of heritage: corporate interests and cultural rights on resource frontiers'. In A Companion to Heritage Studies, ed. William Logan, Máiread Nic Craith and Ullrich Kockel, pp. 337-54. Hoboken: Wiley-Blackwell. doi.org/10.1002/9781118486634.ch24.

Coombe, Rosemary J. and L. Weiss. 2015. 'Neoliberalism, heritage regimes, and cultural rights'. In Global Heritage: A Reader, ed. L. Meskell, pp. 43-69. Hoboken: Wiley-Blackwell. doi.org/10.2139/ ssrn. 2644495 . 
Council of Pacific Arts and Culture and the Secretariat of the Pacific Community. 2012. Regional Culture Strategy Investing in Pacific Cultures 2010-2020. Suva, Fiji: Secretariat of the Pacific Community. Online: www.spc.int/hdp/index2.php?option=com_docman\&task= doc_view\&gid=386\&Itemid=44 (accessed 28 January 2016).

Datt, Halitesh. 2014. 'Fiji soon to have a cultural policy'. Fiji TV Headlines, 1 June. Online: fijione.tv/fiji-soon-to-have-a-culturalpolicy/ (accessed 14 September 2016).

De Cesari, Chiara. 2012. 'Thinking through heritage regimes'. In Heritage Regimes and the State, ed. Regina F. Bendix, Aditya Eggert and Arnika Peselmann, pp. 399-413. Göttingen Studies in Cultural Property Series 6. Göttingen: Universitätsverlag Göttingen.

Foana'ota, Lawrence and Geoffrey White. 2011. 'Solomon Islands cultural policy? A brief history of practice'. In Made in Oceania: Social Movements, Cultural Heritage and the State in the Pacific, ed. Edvard Hviding and Knut Rio, pp. 273-99. Wantage: Sean Kingston.

Forsyth, Miranda. 2015. 'Cultural economics and intellectual property: tensions and challenges for the region'. Asia and the Pacific Policy Studies 2(2): 356-69. doi.org/10.1002/app5.77.

—_. 2013a. 'How can traditional knowledge best be regulated? Comparing a proprietary rights approach with a regulatory toolbox approach'. The Contemporary Pacific 25(1): 1-31. doi.org/10.1353/ cp.2013.0004.

- 2013 b. 'How can the theory of legal pluralism assist the traditional knowledge debate?' Intersections: Gender and Sexuality in Asia and the Pacific 33 (December). Online: intersections.anu.edu.au/issue33/ forsyth.htm (accessed 28 January 2016).

Forsyth, Miranda and Sue Farran. 2015. Weaving Intellectual Property Policy in Small Island Developing States. Cambridge: Intersentia.

France, Peter. 1969. The Charter of the Land: Custom and Colonization in Fiji. Melbourne: Oxford University Press.

Fua, Seu'ula Johansson, Tu ilokamana Tuita, Siosiua Lotaki Kanongata'a and Koliniasi Fuko. 2011. Cultural Mapping, Planning and Policy: Tonga. Nuku'alofa: Secretariat of the Pacific Community. 
Geismar, Haidy. 2015. 'Anthropology and heritage regimes'. Annual Review of Anthropology 44: 71-85.

Geismar, Haidy and William Mohns. 2011. 'Database relations: Rethinking the database in the Vanuatu cultural centre and national museum'. Journal of the Royal Anthropological Institute (n.s.): 133-55. doi.org/10.1146/annurev-anthro-102214-014217.

Graezer Bideau, Florence. 2012. 'Identifying living traditions in Switzerland: Re-enacting federalism through the UNESCO Convention fopr the safeguarding of intangible cultural heritage'. In Heritage Regimes and the State, ed. Regina F. Bendix, Aditya Eggert and Arnika Peselmann, pp. 303-326. Göttingen Studies in Cultural Property Series 6. Göttingen: Universitätsverlag Göttingen.

Gray, Clive. 2007. 'Commodification and instrumentality in cultural policy'. International Journal of Cultural Policy 13(2): 203-15. doi. org/10.1080/10286630701342899.

Harrison, Simon. 2000. 'From prestige goods to legacies: Property and the objectification of culture in Melanesia'. Comparative Study of Society and History 42(3): 662-79. doi.org/10.1017/S0010417500002978.

Hazelwood, David. 1850. A Feejeean \& English and an English and Feejeean Dictionary. Viwa, Fiji: Wesleyan Mission Press.

Hennessy, Kate. 2009. 'A ituvatuva ni vakadidike e Sawau: The Sawau Project DVD'. Visual Anthropology Review 25(1): 90-92. doi. org/10.1111/j.1548-7458.2009.01025.x.

Hesmondhalgh, David and Andy C. Pratt. 2005. 'Cultural industries and cultural policy'. International Journal of Cultural Policy 11(1): 1-14. doi.org/10.1080/10286630500067598.

Hocart, Arthur Maurice. 1929. Lau Islands, Fiji. Bernice. P. Bishop Museum Bulletin, 62. Honolulu: Bishop Museum.

Huffer, Elise. 2010. 'Culture offers opportunities for economic development'. International Network for Arts and Business. Online: www.artsmanagement.net/index.php?module=News\&func=display \& sid=1330 (accessed 12 September 2016). 
Huffer, Elise and Ropate Qalo. 2004. 'Have we been thinking upsidedown? The contemporary emergence of Pacific theoretical thought'. The Contemporary Pacific 16(1): 87-116. doi.org/10.1353/cp.2004.0011.

Jolly, Margaret. 2005. 'Beyond the horizon? Nationalisms, feminisms, and globalization in the Pacific'. Ethnohistory 52(1): 137-66. doi. org/10.1215/00141801-52-1-137.

—_. 1996. 'Woman ikat raet long human raet o no? Women's rights, human rights, and domestic violence in Vanuatu'. Feminist Review 52 (Spring): 169-90.

Kaplan, Martha. 2011. 'Alienation and appropriation: Fijian water and the Pacific romance in Fiji and New York'. In Changing Contexts, Shifting Meanings: Transformations of Cultural Traditions in Oceania, ed. Elfriede Hermann, pp. 221-34. Honolulu: University of Hawai'i Press. doi.org/10.21313/hawaii/9780824833664.003.0014.

Kockel, Ullrich. 2012. 'Borders, European integration and UNESCO heritage: A case study of the Curonian Spit'. In Heritage Regimes and the State, ed. Regina F. Bendix, Aditya Eggert and Arnika Peselmann, pp. 227-246. Göttingen Studies in Cultural Property Series 6. Göttingen: Universitätsverlag Göttingen.

Kooijman, Simon. 1977. Tapa on Moce Island, Fiji. Leiden: E.J. Brill.

Koya Vaka'uta, Cresantia Frances. 2013. 'Anthropological evidence of the 15 intended iTaukei Tapa cloth (masi) motifs pre-dating the creation of the Air Pacific/Fiji Airways logo'. Online: works.bepress.com/cf_ koyavakauta/18/ (accessed 1 February 2016).

Leblon, Anaïs. 2012. 'A policy of intangible cultural heritage between local constraints and international standards: "The cultural space of the yaaral and degal'". In Heritage Regimes and the State, ed. Regina F. Bendix, Aditya Eggert and Arnika Peselmann, pp. 97-118. Göttingen Studies in Cultural Property Series 6. Göttingen: Universitätsverlag Göttingen.

Macpherson, Crawford Brough. 1962. The Political Theory of Possessive Individualism: Hobbes to Locke. Oxford: Clarendon Press.

Merritt, Richard L. and Elizabeth C. Hanson. 1989. Science, Politics, and International Conferences: A Functional Analysis of the Moscow Political Science Congress. London: Lynne Rienner. 
Miller, Daniel. 2001. 'Alienable gifts and inalienable commodities'. In The Empire of Things: Regimes of Value and Material Culture, ed. Fred R. Myers, pp. 91-115. Santa Fe, NM: School of American Research Press.

Nabobo-Baba, U. 2006. Knowing and Learning: An Indigenous Fijian Approach. Suva: Institute of Pacific Studies, University of the South Pacific.

Nand, Salvin S. 2012. 'Protecting and revitalizing traditional knowledge and expressions of culture: For an equitable future in Fiji'. In research papers from The WIPO-WTO Colloquium for Teachers of Intellectual Property Law - Geneva, 2011, ed. A. Mendes-Walsh and S. Meghana, pp. 55-73. Geneva: World Intellectual Property Organization.

Nayacakalou, R.R. 1975. Leadership in Fiji. Melbourne: Oxford University Press.

Otto, Ton and Rane Willerslev. 2013. 'Introduction: Value as theory: Comparison, cultural critique, and guerilla ethnographic theory'. HAU: Journal of Ethnographic Theory 3(1): 1-20. doi.org/10.14318/ hau3.1.002.

Pacific Islands Regional Secretariat. n.d. 'European Development Fund'. Online: www.forumsec.org/pages.cfm/strategic-partnershipscoordination/european-development-fund/ (accessed 28 January 2016).

Pigliasco, Guido Carlo. 2015. 'From colonial pomp to tourism reality: Commodification and cannibalization of the Fijian firewalking ceremony'. In From Romance to Reality: Representations of Pacific Islands and Islanders, ed. J. Schachter and Nancy Lutkehaus. Pacific Studies 38(1-2): 140-81.

. 2012a. 'A tortuous path: From law to policy in Fiji'. Paper presented at the invited session Policy Talk: Processes and Rationales at the International Conference on Sociolegal Conversations across a Sea of Islands, joint Annual Meetings of the Law and Society Association and the Research Committee on Sociology of Law (ISA), co-sponsored by the Canadian Law and Society Association (CLSA), the Japanese Association of Sociology of Law (JASL), and the British Socio-Legal Studies Association (SLSA), Honolulu, HI, 5-8 June. 
2012b. “'Are they evil?”: Denominational competition and cultural demonization on a Fijian island'. People and Culture in Oceania 28: 45-68.

—_. 2011. 'Are the grassroots growing? Intangible cultural heritage lawmaking in Fiji and Oceania'. In Made in Oceania: Social Movements, Cultural Heritage and the State in the Pacific, ed. Edvard Hviding and Knut Mikjel Rio, pp. 273-99. Wantage: Sean Kingston Publishing.

—_. 2010. 'We branded ourselves long ago: Intangible cultural property and commodification of Fijian firewalking'. Oceania 80(2): 237-57.

—_. 2009a. 'Intangible cultural property, tangible databases, visible debates: The Sawau Project'. International Journal of Cultural Property 16: 255-69. doi.org/10.1017/S0940739109990233.

. 2009b. 'Local voices, transnational echoes: Protecting intangible cultural heritage in Oceania'. In Sharing Cultures 2009: International Conference on Intangible Heritage, ed. Sérgio Lira, Rogério Amoêda, Cristina Pinheiro, Joāo Pinheiro and Fernando Oliveira, pp. 121-27. Barcelos: Green Lines Instituto para o Desenvolvimento Sustentável.

—_. 2007. 'The custodians of the gift: Intangible cultural property and commodification of the Fijian firewalking ceremony'. $\mathrm{PhD}$ dissertation. Honolulu: University of Hawai'i at Mānoa.

Pigliasco, Guido Carlo and F. Colatanavanua. 2005. A ituvatuva $i$ vakadidike e Sawau (The Sawau Project). Suva: Institute of Fijian Language and Culture.

Pigliasco, Guido Carlo and Thorolf Lipp. 2011. 'The islands have memory: Reflections on two collaborative projects in contemporary Oceania'. The Contemporary Pacific 23(2): 371-410. doi.org/10.1353/ cp.2011.0045.

Pratt, Andy C. 2005. 'Cultural industries and public policy: an oxymoron?' International Journal of Cultural Policy 11(1): 31-44. doi. org/10.1080/10286630500067739.

Qalo, Ropate. 2015. 'The new power elite'. Fiji Times Online, 11 April. Online: www.fijitimes.com/story.aspx?id=301577 (accessed 28 January 2016). 
Ravuvu, Asesela. 1987. The Fijian Ethos. Suva: Institute of Pacific Studies, University of the South Pacific.

Rawalai, Luke. 2013. 'Masi design concerns'. Fiji Times, 10 February, p. 14.

Riles, Annelise. 2006. Documents: Artifacts of Modern Knowledge. Ann Arbor: University of Michigan Press. doi.org/10.3998/ mpub. 185485.

— 1998. 'Infinity within the brackets'. American Ethnologist 25(3): 378-98. doi.org/10.1525/ae.1998.25.3.378.

Ryle, Jacqueline. 2010. My God, My Land: Interwoven paths of Christianity and Tradition in Fiji. Farnham: Ashgate.

Sahlins, Marshall. 2005. 'Preface'. Ethnohistory 52(1): 3-6. doi. org/10.1215/00141801-52-1-3.

- 1993. 'Cery cery fuckabede'. American Ethnologist 20(4): 848-67. doi.org/10.1525/ae.1993.20.4.02a00100.

Schofield, John. 2014. Who Needs Experts? Counter-Mapping Cultural Heritage. Farnham: Ashgate.

Shore, Cris, Susan Wright and Davide Però (eds). 2016. Policy Worlds: Anthropology and the Analysis of Contemporary Power, New York: Berghahn.

Strathern, Marilyn. 2011. 'Sharing, stealing and borrowing simultaneously'. In Ownership and Appropriation, ed. V. Strang and M. Busse, pp. 23-41. Oxford: Berg.

- 1999. Property, Substance and Effect: Anthropological Essays on Persons and Things. London: Athlone Press.

- 1984. 'Subject or object: Women and the circulation of valuables'. In Women and Property: Women as Property, ed. R. Hirschon, pp. 158-75. New York: St Martin's Press.

Tapaleao Vaimoana. 2013. 'Nike pulls Pacific-style tattoo gear'. New Zealand Herald, 15 August. Online: www.nzherald.co.nz/lifestyle/news/ article.cfm?c_id=6\&objectid=10912467 (accessed January 28 2016). 
Teaiwa, Katerina. 2012. 'Structuring the culture sector across the Pacific: The work of the Human Development Programme of the Secretariat of the Pacific Community'. Paper presented at the Conference on Innovation, Creativity, Access to Knowledge and Development in Pacific Island Countries, College of Asia and the Pacific, The Australian National University, 24-25 September.

Teaiwa, Katerina and Colin Mercer. 2011. Pacific Cultural Mapping, Planning and Policy Toolkit. Noumea: Secretariat of the Pacific Community.

Thomas, Nicholas. 1993. 'Beggars can be choosers.' American Ethnologist 20(4): 868-876. doi.org.10.1525/ae.1993.20.4.02a00110.

—_. 1992. 'The inversion of tradition'. American Ethnologist 19(2): 213-32. doi.org/10.1525/ae.1992.19.2.02a00020.

Throsby, David. 2010. The Economics of Cultural Policy. Cambridge: Cambridge University Press. doi.org/10.1017/CBO9780511845253.

Tomlinson, Matt. 2014. Ritual Textuality: Pattern and Motion in Performance. Oxford: Oxford University Press. doi.org/10.1093/ acprof:oso/9780199341139.001.0001.

- 2009. In God's Image: The Metaculture of Fijian Christianity. Berkeley: University of California Press.

Tuiloma, Eliesa. 2012. 'The potential of cultural industries for development'. Paper presented at the Conference on Innovation, Creativity, Access to Knowledge and Development in Pacific Island Countries, College of Asia and the Pacific, The Australian National University, 24-25 September.

UNESCO. 2014. Culture, Creativity and Sustainable Development: Research, Innovation, Opportunities. Third UNESCO World Forum on Culture and Cultural Industries, Florence, 2-4 October. Online: www. unesco.org/new/fileadmin/MULTIMEDIA/HQ/CLT/pdf/FINAL_ FlorenceDeclaration_1December_EN.pdf (accessed 14 September 2016 
2003. 'Convention for the Safeguarding of the Intangible Cultural Heritage 2003'. Paris. Online: portal.unesco.org/en/ev.php-URL_ ID $=17716 \&$ URL_DO=DO_TOPIC\&URL_SECTION=201.html (accessed 13 September 2016).

Verdery, Katherine and Caroline Humphrey. 2004. Property in Question: Value Transformation in the Global Economy. Oxford: Berg.

von Lewinski, Silke. 2009. 'An analysis of WIPO's latest proposal and the Model Law 2002 of the Pacific Community for the Protection of Traditional Cultural Expressions'. In Traditional Knowledge, Traditional Cultural Expressions, and Intellectual Property Law in the Asia-Pacific Region, ed. Anton Christoph, pp. 109-25. The Netherlands: Kluwer Law International.

Watts, Michael J. 2000. 'Contested communities, malignant markets, and gilded governance: Justice, resource extraction, and conservation in the tropics'. In People, Plants, and Justice: The Politics of Nature Conservation, ed. Charles Zerner, pp. 21-51. New York: Columbia University Press. doi.org/10.7312/zern10810-003.

Weiner, Annette B. 1992. Inalienable Possessions: The Paradox of Keeping-While-Giving. Berkeley: University of California Press. doi. org/10.1525/california/9780520076037.001.0001.

World Intellectual Property Organization (WIPO). 2006. 'Intergovernmental Committee on Intellectual Property and Genetic Resources, Traditional Knowledge and Folklore'. Tenth Session, Geneva, 30 November -8 December. Online: www.wipo.int/edocs/ $\mathrm{mdocs} / \mathrm{tk} / \mathrm{en} /$ wipo_grtkf_ic_10/wipo_grtkf_ic_10_4.pdf (accessed 28 January 2016). 
This text is taken from Tides of Innovation in Oceania: Value, materiality and place, edited by Elisabetta Gnecchi-Ruscone and Anna Paini, published 2017 by ANU Press, The Australian National University,

Canberra, Australia. 